\title{
Social Space and Transnational Social Space: How to Explore a Missing Link?
}

\author{
Saša Božić \\ University of Zadar, Department of Sociology, Croatia \\ e-mail:sbozic@unizd.hr
}

\section{Simona Kuti}

\author{
Institute for Migration and Ethnic Studies, Zagreb, Croatia \\ e-mail:simona.kuti@imin.hr
}

\begin{abstract}
Proliferation of research and publishing on transnational social space (TSS) and transnational social field (TSF) in the last two decades indicates that the issues concerning social ties across the boundaries of nation-states have been getting more prevalent since the so-called transnational turn in social sciences and migration studies in particular. However, the concepts which ought to accurately cover relevant phenomena concerning the spatial composition of social ties and actors across the national boundaries diverge greatly and show that the concepts based on similar or even same terminology demonstrate different understandings of space, social ties and their connection. It is impossible to redefine social spaces and TSSs without multiplying their meanings and creating further confusion about the boundaries and inference of these terms. That is why the authors of this paper attempt to identify areas which contain the connecting points between the concepts and theories on social space as a physical expression of social relations, and the concepts and theories of TSS. The authors also emphasise the areas in theorising about social space and TSS which deserve a special attention in future research endeavours to explain the spatial configuration of social positioning and of social relations in particular empirical cases, in order to contribute to (future) harmonisation of at least some social science terminology and concepts. Finally, in order to achieve some discipline in treatises of social space and TSS, this paper suggests a "procedure" which could be implemented prior to the employment of existing terms and concepts in a study of a particular socio-spatial phenomenon, reaching across borders of nation-states.
\end{abstract}

Key words: social space, transnational social space, transnational social field, transnationalism, methodological nationalism. 


\section{Introduction}

Proliferation of research and publishing on transnational social space (TSS) and transnational social field (TSF) in the last two decades indicates that the issues concerning social ties across the boundaries of nation-states have been getting more prevalent since the so-called transnational turn in social sciences, and migration studies in particular (Faist, 2004). The idea of the "turn" as a grand paradigmatic shift pervaded the most important fields of social science which deal with spatial configurations of societies and mobilities, after the saturation of research and publications on different forms of "transnationalism" at the turn of the new century. In addition to the "transnational turn", social sciences witnessed the ideas of "mobility turn" (Urry, 2000; Sheller and Urry, 2006; Faist, 2013), "spatial turn" (Warf and Arias, 2009) as well as "cosmopolitan turn" (Beck, 2004; Beck and Grande, 2010). All these "turns" have one thing in common - an emphasis on a new kind of social condition which is characterised by the permeation of local, regional, national and transnational levels within different social processes, as well as by the declining importance of physical, geographical space for the development and sustainability of a wide variety of social relations. The number of articles in the social sciences which deal with spatial and transnational phenomena rose considerably in the last decade. ${ }^{1}$ Such trends confirm that social scientists perceive the spatial composition of social ties and actors, particularly across the national boundaries, as an increasingly relevant contemporary social phenomenon.

Yet, their concepts which ought to accurately cover relevant phenomena, diverge greatly $^{2}$ and mostly show that the concepts based on similar or even same terminology demonstrate different understandings of space, social ties and their connection. Until the 1990s and the "discovery" of transnationalism and TSS, social scientists used predominantly the term "social space" to describe the transformation of physical space, particularly in urban settings, through changing social relations. The development of this "tradition" of social theorising on space started with Simmel's (1995) view of social space as the physical, spatial expression of social interdependencies. Simmel's understanding of social space includes the observation that the physical Euclidian or Newtonian space conceived as a container of things becomes relevant only as an expression of social arrangements such as rooms, territories and landscapes (Löw, 2001:62). Since the wider acceptance of Lefebvre's (1991) idea of the social production of space, i.e. of social space as a threefold unity of social prac-

$\mathbf{1}$ For instance, in 2001 - 2004 period SocINDEX research database search with "transnationalism" as a keyword produced 610 articles, and 2.397 articles for "transnational". In the following period (2005 - 2008), the same search produced 866, and 3.315 results, respectively. The number of articles for "transnationalism" kept rising in the following periods as well: 899 (2009 - 2012) and 953 (2013 - 2016); while the number for "transnational" remained substantial, even though somewhat lowered: 3.031 (2009 - 2012), and, 3.195 (2013 - 2016).

2 Even the terms which cover very similar transnational composition of social ties and relations vary significantly. Beside transnationalism and TSS, terms such as "transnational social field" (Levitt and Glick Schiller, 2004) and even "transstate space" (Faist, 2008) emerged. The term "transnational social field" (TSF) eventually gained an even wider popularity than the term "transnational social space" (TSS). 
tice, representation of space and space of representation, social space is not seen as a static place, but rather as a dynamic unity of physical and mental spaces. The term and the concept has further proliferated and influenced the construction of new concepts such as "thirdspace" (Soja, 1996) and "three-by-three matrix" of space and space-time (Harvey, 2005:103) in social geography and urban sociology.

However, social space as a concept based on a metaphor, used mainly in sociology to describe the "distance" and "closeness" between actors based on their social "positions" (Sorokin, 1998) regardless of their physical or geographic positions, has developed separately from theorising about the social transformation of physical space. According to Löw (2001) and Harvey (2005), social theorists who use spatial metaphors in this type of theorising only use the properties of Euclidian or absolute physical space in order to conceive and describe regularities of social relations and positioning within imagined, abstract social space. Majone (1972:240) even tried to translate these intuitive notions of similarity and distance developed by Sorokin in 1927 in terms of general metric spaces using mathematical logic.

Since the 1960s different authors tried to conceptualise the relation between the position of social actors in abstract social space and their position in geographic localities, i.e. socially transformed physical, absolute space. Feldman and Tilly (1960) addressed the interaction of social and physical space in their research on congruence between physical and social distance of urban residents with different professional backgrounds and residential patterns. This research is embedded in the tradition of urban ecology of the Chicago School. However, the most important "spatially-strong" discourse (Friedrich Silber, 1995) and theory that addresses the relation between social space as an abstract multidimensional space and social compositions in physical spaces and concrete localities is Bourdieu's. He tried to explain the difference in positioning of social actors in abstract, multidimensional social space based on the composition and type of their capital and their positioning in the localities of physical space. He claims that there is a relative congruence of social and physical space (Bourdieu, 2010). When actors are close in physical, yet distant in social space, there cannot be an accumulation of social capital. Physical closeness of socially distant actors is usually perceived as unbearable. This is why socially distant actors tend to separate residentially and otherwise in physical space and in urban settings generally (Bourdieu, 2010).

The concepts and theories of TSS and TSF, however, rarely make any reference to the concepts and theories of social space. Authors who are generally perceived as the founders of the research and theorising on TSS or TSF (e.g. Faist, Pries, Levitt and Glick Schiller) mention theories and concepts of social space only as part of a general overview of the authors who dealt with problems of spatial configuration of social relations. Kivisto (2003a) notes that Bourdieu seems to have inspired the formulation of the term "transnational social fields" by Glick Schiller, Basch and Szanton Blanc (1992), but also emphasises that the connection between Bourdieu's concept and the concept of TSFs is not explicitly explained. Only several authors tried to expand transnationally the elements of the concepts and theories of social space, which were reserved for nationally bounded societies (e.g. Kivisto, 2003b; Weiss, 2005; Buchholz, 2016; Steinmetz, 2016; Zechner, 2017), but without explicitly 
connecting and unifying a particular concept or theory of social space with a specific concept or theory of TSS.

This is unfortunate considering the persisting weakness of social science, its inherent inability to standardise its terminology, concepts, theories and consequently to enable at least a limited amount of knowledge accumulation. The claim that social science disciplines lost any discipline (Sartori, 1984:50) is still relevant today. Social scientists rarely consult the criteria set for the invention of new terms and foundation of the new concepts, such as familiarity, resonance and parsimony (Gerring, 1999). Due to arbitrary use, some promising terms and concepts already lost their explanatory power. The term "transnationalism", e.g., became a catch-all phrase for transnational phenomena, and the proliferation of immigrant transnationalism research in the 1990s was already described in terms of natural disasters such as deluge (Morawska, 2003:619).

It is impossible to redefine social spaces and TSSs without multiplying their meanings and creating further confusion about the boundaries and inference of these terms. This is why we shall try to find and identify the areas which contain the connecting points between the concepts and theories on social space as a physical expression of social relations, and the concepts and theories of TSS. We shall also emphasise the areas in theorising about social space and TSS which deserve a special attention in future research endeavours to explain the spatial configuration of social positioning and of social relations in particular empirical cases. Hopefully, this might contribute to (future) harmonisation of at least some social science terminology and concepts, i.e. of the concept of social space and TSS. In order to achieve some discipline in treatises of social space and TSS, we shall attempt to propose a "procedure" which ought to be implemented prior to the employment of existing terms and concepts in one's study of a particular socio-spatial phenomenon reaching across borders of nation-states.

\section{From spatial metaphors towards conceptual consistency in dealing with social space}

The use of metaphors and particularly spatial metaphors in social sciences is not a contemporary trend, but follows the development of social sciences, and sociology in particular. Since the beginnings of social science disciplines, social theorists have used spatial metaphors to establish and explain the main principles of social processes and particularly of social relations. Spatial metaphors can have a central place in social theories, but there are also "weaker" theoretical usages of these metaphors (Friedrich Silber, 1995). However, "[n]either a theorist's overall metaphorical propensity nor the relative strength of his theoretical usage of metaphors [...] bear any clear relation to his commitment to "scientific" criteria [...] for sociology as a discipline" (Friedrich Silber, 1995:326). This is not to say that metaphors have a negative role in social theories. Urry (2000:21) argues that sociological thinking, like any other form of thought, cannot be achieved non-metaphorically. True enough, since the beginning of the $20^{\text {th }}$ century it has been almost impossible to make any sociological explanation of social relations without invoking social distance, "vertical 
dimension" of social life, central and marginal positions in the society, etc. Yet, if social theorising is to achieve any form of rigour, it has to try to differentiate between the object of its inquiry and the mental images (i.e. metaphors) used to explain it. This is particularly important when spatial metaphors are used to theorise about two different, yet interconnected topics - the relative positions within the relation of different social actors, and their role in the transformation of geographical, physical space. If one is to avoid methodological spatialism, which we define as an indiscriminate use of spatial metaphors without references to the debates and social theories about the relation between society, time and space, it is important to be aware of the contemporary differentiation of the notions of social space in social sciences.

Manderscheid (2010) made a clear distinction between different notions of social space in social theories and research. Her simple distinction of the existing notions of social space as a material environment of social groups, as a relational setting of positions, as a dialectical approach to the society-space relation and as a subject of deconstruction of society-space duality (Manderscheid, 2010:747) represents an important contribution to ordering of a messy field of study. The fleeting use of metaphors might help authors to "visualise" and describe the abstract notions of actors' "positioning" in structurally conceived society. However, authors dealing with social space should not overuse the analogy with the Euclidian or Newtonian absolute space without referring to actors' positions in a geographical space and without considering the influence of social positioning of interrelated actors in physical space on the reconfiguration of society and space. Nor should authors, in their efforts to conceive pluri-local and transnational social configurations, disregard previous concepts of social space. Otherwise, the continuing multiplication of meanings of the term "social space" will make it useless for serious attempts to explain spatial configuration of social positioning and relations of social actors. This is why we propose that researchers dealing with social space and TSS consult previous concepts and theories and try to answer several questions before uncritically employing those terms.

1) The first question refers to the existing types of conceptions of social space. Before starting the research, or any treatise of social space, it is advisable to check whether the particular conception of space has already been discussed within the previous approaches described, e.g. by Manderscheid (2009). Authors should at least consult the differences in the approaches to social space conceived as a material environment of social groups ${ }^{3}$, as a relational setting of positions, social space

3 While social scientists, and particularly sociologists, have mostly overcome what Manderscheid (2010:747-748) described as the "common" or "traditional" usage of the term social space (in geography, architecture, social work, or urban sociology), which carries the notion of social space as a geographical territorial environment of individuals or groups, many still understand space as something natural, objective, and antecedent of social formations (Manderscheid, 2010:748). The extreme version of "traditional" understanding of social space i.e. overt spatial determinism, presupposes the direct influence of material environment and place on social relations. Practical consequences of such extremes can be found in the work of architects and urban planners who try to "build" social relations by building their anticipated physical environment (Manderscheid, 2010:748). 
as a dialectical approach to the society-space relation and social space as a subject of deconstruction of society-space duality (Manderscheid, 2010:747). This first step might help researchers to take into consideration other conceptions of social space already dealt with in the work of previous authors, and to avoid indiscriminate use of spatial metaphors which we termed "methodological spatialism".

2) The second, but related question refers to inquiries about the autonomy of space from social relations, socially measured time and their interconnection. Authors cannot avoid dealing with the question of the nature of space in general, regardless of their initial research motivation. They might be interested only in the flow of information, goods and ideas among dispersed members of a migrant family across the boundaries of nation-states. However, before defining such arrangements as TSSs they should also take into account e.g., the role of geographical distance, daily rhythms in different time zones, political control of national boundaries, use of timespace compressing communication technologies, family members' perceptions and experience of localities and geographic distances, i.e. the role of spatial transformation in such arrangements. Therefore, they should try to answer the question how their concept deals with and fits in the existing conceptions of space conceived as absolute, relative and/or relational. ${ }^{4}$

Absolute space is conceived as fixed and can be used to record and plan events within its frame. This space was firstly conceived by Newton and Descartes and it stands for a pre-existing and immovable grid within which objects are placed. Without it, there could be no standardised measurement and calculation of physical distances, nor planning of daily activities in all spheres of life. Practically, it is a Euclidian geometrical space and therefore the space of cadastral mapping and engineering practices. Socially, absolute space is a space of private property and other bounded territorial arrangements such as states, administrative units, city plans and urban grids (Harvey, 2005:94).

Ideas about relative space, including social scientific discourse, are based on Einstein's inferences about the relationship between space and time. He pointed out that all measurement depends on the frame of reference of the observer. The idea of simultaneity in the physical universe has to be abandoned because it is impossible to understand space independent of time. Therefore, our terminology also has to change and adopt "space-time" or spatiotemporality. This is why on everyday level the space of transportation relations differs greatly from the spaces of private property (Harvey, 2005:95).

The relativist tradition of thought on space differs from the absolutist tradition in one very important issue - the absolutist view of space differentiates space and objects,

${ }^{4}$ We are aware that a particular study depends on a research topic, main research questions, methodology, available resources, etc. Nevertheless, we are suggesting the authors to consider the selected issues at least initially, in order to achieve a clearer definition of the employed concepts. 
while the relativist view is based on a view that space is given by the structure of positions of these objects (Löw, 2001:17). The basis for action, including the social action, is to be found in the production of space (Löw, 2001:18). Empirical research in sociology leans on the findings of Einstein and emphasises fragmentation and mobility of spatial structures, and treats space as a mobile, and not a homogenous entity (Löw, 2001:21).

Objections to the conceptions of space and time as absolute were particularly prominent in the arguments of Leibniz, who introduced relational thinking in the discourse on space. Within this perspective, any kind of process does not occur in space but sets its own spatial frame (Harvey, 2005:96). "The concept of space is embedded or internal to process. This very formulation implies that, as in the case of relative space, it is impossible to disentangle space from time. We must therefore focus on the relationality of space-time rather than on space in isolation. The relational notion of space-time implies the idea of internal relations; external influences get internalised in specific processes or things through time [...]. An event or thing at a point in space cannot be understood as an appeal to what exists only at that point. It depends upon everything else going on around it [...]" (Harvey, 2005:96).

Harvey does not resolve ontological questions about the primacy of absolute, relative or relational space or the questions whether one concept of space can embrace the other two, but rather maintains that absolute, relative and relational space are in a constant interplay. ${ }^{5} \mathrm{He}$ is more interested in a dialectical tension between all three concepts (Harvey, 2005:98).

The idea of a constant interplay and dialectic tension between different concepts of space, as well as Lefebvre's ideas of social space as a threefold unity of social practice, representation of space and space of representation (Lefebvre, 1991), enabled Harvey (2005:103) to construct a "three-by-three matrix" of space and space-time in social geography and urban sociology. This does not mean that every researcher interested in spatial composition of social relations and construction of social spaces should take the same path, but rather that upcoming research on social space should at least initially consider its presuppositions of space in relation to absolute, relative and relational space.

Social scientists were already influenced by the concepts of absolute and particularly relative/relational space when they theorised on space, but also on other topics. ${ }^{6}$ Some authors went even further and tried to map relative social space using specific variables constitutive of a particular transnational space conceived as relative space, rather than employing unsuitable representation of absolute space in traditional (i.e.

5 He gives an example of Ground Zero which is at the same time absolute, relative and relational space (Harvey, 2005:98).

${ }^{6}$ Löw (2001:21) emphasises that the work of Piaget, Elias, Ciompi, Läpple, Sennett and Grosz was directly influenced by the relativist notion of space in physics and that these authors explicitly refer to Einstein. 
state-centred) cartography. Carling (2003:337) attempted to capture the geographical configuration of Cape Verde's migration-related transnational connections using three variables: the proportion of people who have relatives in different countries, the distribution of remittances and the distribution of preferred destinations among prospective emigrants. Voigt-Graf (2004) on the other hand, constructed a map of migrant transnational spaces constituted by nodes that are fixed or anchored places in networks, and by flows between these nodes. She analysed specific transnational spaces constructed by Punjabis, Kannadigas and Indo-Fijians and then developed the generalised cartographic models of transnational spaces which differ greatly from the standard cartographic models (Voigt-Graf, 2004). Yet, these attempts are very rare and the inclusion of relative and relational aspects of social space in the research on transnational social configurations remains an exception.

Regardless of one's ontological and epistemological preferences, it becomes obvious that every spatial phenomenon and every idea of social space conceived in research questions can be observed as absolute, relative and relational space. E.g., a research on residential segregation, although primarily concerned with the social placement within absolute space, cannot disregard wider, durable social and economic processes which have led to geographic concentration of groups with specific type of economic and cultural capital. Nor can it disregard these groups' existing relations with geographically absent but socially present members, as well as their experience of the place in relation to their previous residential patterns or future visions based on multifaceted experiences of space and place. On the other hand, researchers dealing with e.g. transnational communities cannot disregard the consequences of intensified transfer of goods or remittances across the (multiple) boundaries of nation-states on neighbourhood's infrastructure, urban development and other changes within absolute space. Nor can they ignore the visions of distant places occupied by their emigrant friends and relatives and their role in transformation of the community.

3) Finally, researchers dealing with social space should, at least initially, in conceiving their research try to consider how the spatial phenomenon in question performs in absolute space, how it performs as relative space, and as relational space. They should attempt to answer the question in what way are absolute, relative and relational spaces interlinked in their study of a particular spatial phenomenon. This might be the most difficult question to answer, but its relevance is undeniable, because if one aspect of a particular phenomenon is neglected, its overall picture could be distorted.

It is quite common in the study of TSS to neglect the aspects of absolute space within which actors who construct relational TSS act in their everyday lives. Despite space and time compressing technologies which enable instant communication, transfers of information, resources and even emotions, geographic distance still plays an important factor in decision making of migrant families. E.g., Chinese transnational families in Croatia (Kuti and Božić, 2011; Kuti and Božić, 2016) consider the geographic distance between Croatia and the province of Zhejiang in China, from where they immigrated, as an important factor in deciding not to bring their 
children and parents to Croatia. ${ }^{7}$ Once they decide to invest, e.g. in a restaurant, its unique form will change the appearance of the street and become a new focal point for the relational space of the local population. Short geographic distance, on the other hand, enables migrants from North-Western Croatia in Southern Austria to visit their towns and villages every weekend and change the infrastructure as well as the physical appearance of whole towns and villages. Stricter border controls as a direct intervention in absolute, geographic space between Croatia and Slovenia after the "refugee crisis" in 2015 had a reverse effect and influenced the changes of relative space comprised of the localities in North-Western Croatia and Southern Austria by slowing down the traffic and "prolonging" the routes between Croatia and Austria.

Similar problems might emerge if we disregard the relative and relational aspects of social space in studying e.g., the social integration of immigrants in the urban context and concentrate on interaction patterns in the localities of physical space. Cultural and emotional aspects of relational space, which include experiences of distant localities, as well as a concealed impact of physically absent, but socially present members of migrant groups and networks, can have an important effect on the migrants' "positive" and/or "negative" propensity to e.g. participate in local initiatives and face-to-face interactions (see Erdal, 2013; Erdal and Oeppen, 2013).

At least a limited degree of terminological and conceptual harmonisation could be achieved if researchers dealing with social space initially answered the proposed questions and took into consideration the previous classifications of spatial concepts. Additionally, a heuristically fruitful cross-fertilisation (Vertovec, 2003) of concepts and research of spatial phenomena could be expected if the researchers who initially favour a specific approach and an idea of social space answered the question how their phenomenon of interest performs in absolute space, how it performs as relative space, and as relational space. Such an endeavour could enable new insights and the development of a whole field of study.

\section{Elements of absolute, relative and relational social space within the concepts of transnational social space}

There are many elements in the existing concepts of TSS that already contain the premises of social space conceived as absolute, relative and relational. Authors who developed the research of TSS noticed that, unlike absolutist understanding of space which do not consider "how places and territories may also be a product of the constitution of spaces (...) [t] he relativist understanding of space has guided thinking concerned with the constitution, construction, formation, and development of social space" (Faist, 2005:761). Or, in other words, "spaces do not exist independently of social relations defined by the positions of actors, social action, and social goods such as status and power" (Faist, 2005:760). Yet, these far-reaching conclusions were not explicitly integrated in the specific propositions on the qualities of TSSs.

${ }^{7}$ Along with the factors such as the lower living costs in China and the wish to enable their children an education in Chinese. 
To our best knowledge, Pries (2008) is the only author who explicitly included a combination of absolute, relative and relational space in his treatise of transnationalisation of social phenomena. He believes that we can talk about social space when we consider the relationship between the social and the space as a surface, because social life is structured through the dimensions of space as a surface (Pries, 2008:94). Relational positions are inherent to social space, and relational positions of relevant elements determine how social space is constructed. The most important elements, which enable the emergence of social space, appear typically as the space of artefacts, space of practice and symbolic space (Pries, 2008). Additionally, space as a surface and the social space with its analytical aspects of space of artefacts, space of practice and symbolic space, have to be put in a relationship with time-space compression (Pries, 2008:94). It is possible to explain the positional relations of artefacts, social practices and symbolic representations only through their historical emergence and construction. The absolutist time concept proceeds from an objectively given time and from the possibility of its measurement as clock-time. However, the relativist time concept emphasises the dependence of time and time experience on the acting people. Societies "pulsate" in their particular space-time and even the national societies can have different subjectively experienced space-times (Pries, 2008:95). Social spaces are therefore configurations of social practices, artefacts and systems of symbols which are characterised by their density and importance in time and in geographic space (Pries, 2008:229).

When we look for the socially relevant units of analysis, we should not necessarily (and a priori) start with classes, nations, communities or cultures, but with those concentrated and relatively durable social spaces that structure social reality in geographic space and time (Pries, 2001:22). Social spaces in their transnational variant are "pluri-local frames of reference which structure everyday practices, social positions, biographical employment projects, and human identities, and simultaneously exist above and beyond the social contexts of national societies" (Pries, 2001:23). Therefore, it is quite important to emphasise that the surface space or geographic space is an implicit part of TSS. Social relations become more fluid, but they are not dissolved in the atmosphere, or simply constrained in "cyberspace". It is always important to determine which spatial units of analysis are appropriate for the study of the social or of "social spaces" (Pries, 2001:23).

Pries (2005:176) also described ideal-typical configurations of societal and geographic spaces and the processes affecting them. He differentiates geographic and societal dimensions and combines them with absolutist and relativistic concepts of space, thus enabling the analysis of geographic reach and characteristics of different societal spaces (Pries, 2005:175-180). TSSs are not the only form of spatial reconfiguration of social relations in the contemporary world. There are other social forms which are based on restructuring social relations in time and space, i.e. diasporas, supra-national formations, but also shrinking and disintegration of national containers in the process of re-nationalisation. In order to analyse these new configurations, various frames of reference - local, micro-regional, national, macro-regional and global - have to be combined, instead of replacing one frame (for example the national) with another (for example the global) (Pries, 2005:174). 
Unfortunately, social scientists and researchers who deal with transnationalism in general and TSS in particular rarely employ Pries' concepts, but simply describe intensified communication and exchange across the boundaries of nation-states between different types of actors (from individuals and families to organisations and institutions). They prefer concepts which do not explicitly refer to absolute and relativist space and which do not integrate these aspects in their models of TSS. Less complex models are probably more economic for the conceptualisation and completion of research projects on TSSs, which usually deal with interconnected localities in several countries. However, neglecting absolute and relativist elements of these spaces cannot result in completely accurate accounts and inferences. ${ }^{8}$ Explicit reference to social space, conceived as absolute, relative and/or relational by authors who deal with TSP, would not only help the terminological and conceptual harmonisation, but would also enable them to clarify which spatial elements actually constitute the phenomenon in question.

\section{Transnationalising the social space ${ }^{9}$}

Territorialisation and boundary construction are important aspects of social space and the most important way in which absolute space is conceived, as well as socially and politically managed. As Penrose (2002:279) points out: "Human beings may respond to the latent material and emotional qualities of space wherever they encounter them but they only begin to harness these sources of power when they transform space into places and territories". Territoriality and boundary making represents a geographic strategy which connects society and space (Penrose, 2002:279). By the end of the 20th century, the principle of the division of societal arrangements through boundary making and territorial organisation became universal and people tend to be bound to specific places while they value and protect territories as long as these territories fulfil fundamental emotional and material needs (Penrose, 2002:293). Compartmentalisation of the world into nation-states, constant social and political production and reproduction of firmly bounded territories became a social and political fact. The nation-state was originally forged through connecting the local units people were fiercely attached to (Beck and Sznaider, 2006:8). Nation-state was not considered to be natural, but rather a soulless and artificial Gesellschaft, compared to the local Gemeinschaft (Beck and Sznaider, 2006:8). Yet, the process of societal integration within confined boundaries and the general standardisation of time, as well as of Euclidian container space, created the idea of natural repositories of social relations in the form of firmly delimited nation-states which are supposed to contain

8 Contemporary projects on transnational social relations rarely integrate or even juxtapose different concepts of TSS, let alone consider the previous concepts of social space, although there were some notable attempts (e.g. Kosygina, 2017).

9 The following part of the article mainly deals with scholarship on transnationalism and transnational migration. Including recent conceptions of global processes and "globalisation" within sociology and social geography would supersede the spatial limitations of the article, direct the discussion towards a separate field of inquiry (cf. Pries 2001), and potentially other discipline(s). 
a single, unified national society. This idea became prevalent in social sciences and the observation and research of social configurations across national boundaries were confined to the fringes of economics and sociology. However, an intensified research on transnational phenomena and particularly migrant transnationalism by the end of the 20th century enabled new, critical methodological insights based on the critique of methodological nationalism (e.g. Wimmer and Glick Schiller, 2003) and conflation of societies and nation-states. Methodological cosmopolitanism, on the other hand, is based on the idea that researchers should be sensitive and open to a variety of perspectives, and must observe and investigate the boundary-transcending of social and political agents through very different lenses (Beck and Sznaider, 2006:18). Social scientists should conceptualise and thematise the relational patterns "transnational", "global-local", "global-national", "national-global" or "global-global" with e.g. local, national, transnational (or translocal) or with a global focus (Beck and Sznaider, 2006:17-18).

Social scientists who research the social space of neighbourhoods, local communities, urban development, social segregation and other forms of social relations dependent on absolute space cannot disregard the consequences of methodological cosmopolitanism and particularly its transnational social dimension. Pries (2005:174) noted that the differentiation of geographic and societal dimensions, and of absolutist and relativistic concepts of space, gives us an opportunity to overcome the container concept of national societies and to differentiate between ideal types of societal spaces in relation to their geographic reach and characteristics.

His typology takes into account two basic forms of geographic-societal spaces beyond, alongside and above the previously dominant national society paradigm. The first, basic form of geographic-societal space preserves "the double exclusiveness of societal and geographic space found in the absolutist approach" (Pries, 2005:174). Relations and links between the national containers can be intensified (inter-nationalization); the geographic-societal reach of these containers can be reduced (renationalization) or widened (supra-nationalization and globalization) (Pries, 2005). The second form of geographic-societal space is based on the detachment of the exclusive relationship between societal and geographic space, which allows the "formation of pluri-local, dense and durable agglomerations of societal practices, symbols and artefacts. This can lead to the development of satellites attached to an imagined 'motherland' or nation (diaspora building), to the combination of the global as one place and local societal spaces (glocalization), and to the emergence of a framework of transnational local places building coherent societal spaces (transnationalization)" (Pries, 2005:175).

This does not mean that every researcher interested in social spaces geographically constrained within the boundaries of nation-state must take the same approach. However, they should not disregard the fact that what might appear as a territorially bounded phenomenon also has cosmopolitan and transnational dimensions. Nor should they disregard the fact that a phenomenon that appears as geographically limited might heavily depend on intensified pluri-local ties and exchanges. Authors who were aware of the importance of transnational processes which permeate social spaces, conceptually confined to local and national level, mainly tried to transnationalise the 
existing concepts of social space limited to national societies. The most popular concepts which were recently transnationalised belong to Bourdieu, who originally did not design a model of social space outside or beyond the nationally bounded society.

For instance, Weiss (2005) has attempted to transnationalise Bourdieu's concepts of economic, cultural, social and symbolic capital, as well as practices of distinction, social closure and strategies to overcome social barriers, in her research of social positioning of highly skilled migrants from a world system perspective. Nowicka (2013) has analysed the (transnational) social positioning of Polish entrepreneurs in Germany applying a transnationalised version of Bourdieu's notion of capital. She has concluded that "[b]y analysing how the different forms of capital transfer across national borders, Bourdieu's model can be adapted well to a transnational perspective on migration" (Nowicka, 2013:43). Buchholz (2016) has examined strategies for revising and applying Bourdieu's field theory at a global level, including denationalisation of Bourdieu's concept of "national capital". Finally, Zechner (2017) has analysed a multilocal transnational habitus of older persons at the time of retirement. Her research shows that transnational habitus of middle-class interviewees is challenged by weakening of physical and mental health, as well as by public policies influencing transnational transferability of benefits and accessibility of services (Zechner, 2017:586).

Transnationalisation of the existing concepts of social space might bring valuable insights into the life of a particular group (e.g. migrants, retirees etc.) or deliver some explanations of particular social processes within and beyond national societies. However, without explicitly connecting and unifying a particular concept or theory of social space with a specific concept or theory of TSS, social science will remain dependent on the concepts and theories which were not designed for the explanation of the detachment of societal and geographic space. The refreshing of the concepts from an era of methodological nationalism might be heuristically fruitful, but revamped "analogical theorising" will hardly bridge the existing conceptual and theoretical gaps and will not produce a unified theory of social space. Social scientists still have to create a concept which will also fully incorporate and thematise the following relational patterns: "transnational", "global-local", "global-national", "national-global" or "global-global" with e.g. local, national, transnational (or translocal) or with a global focus (Beck and Sznaider, 2006:17-18).

\section{Conclusion}

Paradigmatic "turns" at the beginning of the new millennium placed an emphasis on a new kind of social condition, which is characterised by a permeation of local, regional, national and transnational levels within different social processes. Studies of TSS particularly highlight the declining importance of physical, geographical space for the development and sustainability of a wide variety of social relations. The concepts and theories of TSS and TSF, however, are mainly disconnected from the concepts and theories of social space. This perpetuates an epistemological impasse which is characterised by social sciences' inherent inability to standardise its termi- 
nology, concepts, theories, and consequently to enable at least a limited amount of knowledge accumulation. New approaches and new definitions of social spaces and TSSs multiply their meanings and create superfluous confusion about the boundaries and inference of these terms. This is why we attempted to identify the areas which contain the connecting points between the concepts and theories on social space as a physical expression of social relations and the concepts and theories of TSS. We also emphasised the areas in theorising about social space and TSS which deserve a special attention by the researchers dealing with the spatial configuration of social positioning and of social relations in order to help the (future) harmonisation of at least some social science terminology and concepts.

We proposed a "procedure" which might be implemented prior to the employment of the existing terms and concepts in one's study of a particular socio-spatial phenomenon. Firstly, the authors and researchers dealing with spatial configuration of social relations would have to establish whether their conception of space has already been discussed within the approaches described e.g. by Manderscheid (2009). The authors might at least consult the differences in the approaches to social space conceived as a material environment of social groups, social space as a relational setting of positions, social space as a dialectical approach to the society-space relation and social space as a subject of deconstruction of society-space duality (Manderscheid, 2010:747). Further on, they could answer the question how their concept deals with and fits in the existing conceptions of space conceived as absolute, relative and/or relational. Regardless of their ontological and epistemological preferences, authors should not simply disregard the fact that at least a fragile consensus is built on the statement that spatial phenomena can be observed through a prism of absolute, relative and relational space. Finally, researchers dealing with social space should consider the performance of the phenomenon within absolute space of territorially compartmentalised world, as well as its performance, as a relative and relational space constituted by the specific practices of actors. They should answer the question in what way are absolute, relative and relational space interlinked in their study of a particular spatial phenomenon. We maintain that at least a limited degree of terminological and conceptual harmonisation could be achieved if researchers dealing with (transnational) social space took into consideration the previous classifications of spatial concepts and answered the proposed questions, potentially enabling the development of a whole field of study.

So far, social scientists who dealt with TSS preferred concepts which do not explicitly refer to absolute and relativist space and which do not integrate these aspects in their models of TSS. They preferred less complex models that are probably more economic for the conceptualisation and completion of research projects on TSS, which mainly deal with interconnected individuals or families and rarely include localities in more than two countries. However, they mainly neglected absolute and relativist elements of these spaces, which resulted with incomplete accounts and inferences. Explicit reference to social space, conceived as absolute, relative and/or relational, would not only help the terminological and conceptual harmonisation of the notions of TSS, but would also enable authors to clarify which spatial elements actually constitute the phenomenon in question. 
On the other hand, we are aware that it is impossible to expect complete harmonisation of social scientific terms and concepts in the conditions of intensified emphasis on research originality and inventiveness, which often leads to the creation of multiplying (and somewhat overlapping) concepts. Nevertheless, taking into account the proposed "procedure" and minimal guidelines set out in this article could pave the way towards certain knowledge accumulation within the field of study on TSS.

\section{References}

1. Beck, U. (2004). The Cosmopolitan Turn, in: Gane, N. (Ed.). The Future of Social Theory. London: Continuum, 143-166.

2. Beck, U. and Grande, E. (2010). Varieties of second modernity: the cosmopolitan turn in social and political theory and research. The British Journal of Sociology, 61 (3): 409-443.

3. Beck, U. and Sznaider, N. (2006). Unpacking cosmopolitanism for the social sciences: a research agenda. The British Journal of Sociology, 57 (1): 1-24.

4. Bourdieu, P. (1985). Sozialer Raum und „Klassen“. Frankfurt a/M: Suhrkamp.

5. Bourdieu, P. (2010). Ortseffekte, in: Balazs, G.; Beaud S.; Bourdieu P.; Broccolichi S.; Champagne, P.; Christin, R.; Lenoir, R.; Oeuvrard, F.; Pialoux, M.; Sayad, A.; Schultheis, F.; Soulié, C. (Eds.). Das Elend der Welt. Konstanz: UVK, 117-123.

6. Buchholz, L. (2016). What is a global field? Theorising fields beyond the nationstate. The Sociological Review Monographs, 64 (2): 31-60.

7. Carling, J. (2003). Cartographies of Cape Verdean transnationalism. Global Networks, 3 (4): 335-341.

8. Erdal, M. B. (2013). Migrant Transnationalism and Multi-Layered Integration: Norwegian-Pakistani Migrants' Own Reflections. Journal of Migration and Ethnic Studies, 39 (6): 983-999.

9. Erdal, M. B. i Oeppen, C. (2013). Migrant Balancing Acts: Understanding the Interactions Between Integration and Transnationalism. Journal of Migration and Ethnic Studies, 39 (6): 867-884.

10. Faist, T. (2005). The Transnational Turn in Migration Research: Perspectives for the Study of Politics and Polity, in: Povrzanović - Frykman, M. (Ed.). Transnational Spaces: Disciplinary Perspectives. Malmö: Malmö University (IMER), 11-45.

11. Faist, T. (2008). Transstate Spaces and Development. Some Critical Remarks, in: Pries, L. (Ed.). Rethinking Transnationalism. The Meso-Link of Organisations. London, New York: Routledge, 63-79.

12. Faist, T. (2013). The mobility turn: a new paradigm for the social sciences? Ethnic and Racial Studies, 36 (11): 1637-1646.

13. Feldman, A. S. and Tilly, C. (1960). The interaction of social and physical space. American Sociological Review, 25 (6): 877-884.

14. Friedrich Silber, I. (1995). Space, Fields, Boundaries: The Rise of Spatial Metaphors in Contemporary Sociological Theory. Social Research, 62 (2): 323-355.

15. Gerring, J. (1999). What makes a concept good? A criterial framework for understanding concept formation in the social sciences. Polity, 31 (3): 357-393. 
16. Glick Schiller, N.; Basch, L. and Szanton Blanc, C. (1992). Transnationalism: A New Analytic Framework for Understanding Migration, in: Glich Schiller, N.; Basch, L. and Szanton Blanc, C. (Eds). Towards a Transnational Perspective on Migration: Race, Class, Ethnicity, and Nationalism Reconsidered. New York, Annals of New York Academy of Sciences, vol. 645, 1-24.

17. Harvey, D. (2005). Spaces of neoliberalization: towards a theory of uneven geographical development. Wiesbaden, Stuttgart: Franz Steiner Verlag

18. Kivisto, P. (2003a). Social spaces, transnational immigrant communities, and the politics of incorporation. Conference Papers - American Sociological Association, 2003 Annual Meeting, Atlanta, 1-39.

19. Kivisto, P. (2003b). Social spaces, transnational immigrant communities, and the politics of incorporation. Ethnicities, 3 (1): 5-28.

20. Kosygina, L. (2017). Re-nationalisation, inter-nationalisation, and supranationalisation in the re/production of transnational social space(s): the case of Kazakhstanis residing in Novosibirsk. Journal of Ethnic and Migration Studies, 43 (6): 1026-1043.

21. Kuti, S. and Božić, S. (2011). Analitičke dimenzije za istraživanje transnacionalnih aktivnosti: Primjer kineskih migranata u Hrvatskoj. Revija za sociologiju, 41 (3): 315-340.

22. Kuti, S. and Božić, S. (2016). Transnacionalni socijalni prostori. Migrantske veze preko granica Hrvatske. Zagreb: Jesenski i Turk, Hrvatsko sociološko društvo.

23. Lefebvre, H. (1991). The Production of Space. Oxford: Blackwell.

24. Levitt, P. and Glick Schiller, N. (2004). Conceptualizing Simultaneity: A Transnational Social Field Perspective on Society. International Migration Review, 38 (3): 1002-1039.

25. Löw, M. (2001). Raumsoziologie. Frankfurt a/M: Suhrkamp.

26. Majone, G. (1972). Social space and social distance: Some remarks on metric methods in data analysis. Quality and Quantity, 6 (2): 239-252.

27. Manderscheid, K. (2010). Social Space, in: Hutchinson, R. (Ed.). Encyclopedia of Urban Studies. Los Angeles, London: Sage, 747-751.

28. Morawska, E. (2003). Disciplinary Agendas and Analytic Strategies of Research on Immigrant Transnationalism: Challenges of Interdisciplinary Knowledge. International Migration Review, 37 (3): 611-640.

29. Nowicka, M. (2013). Positioning strategies of Polish entrepreneurs in Germany: Transnationalizing Bourdieu's notion of capital. International Sociology, 28 (1): 29-47.

30. Penrose, J. (2002). Nations, states and homelands: territory and territoriality in nationalist thought. Nations and Nationalism, 8 (3): 277-297.

31. Pries, L. (2001). The Approach of Transnational Social Spaces: Responding to New Configurations of the Social and the Spatial, in: Pries, L. (Ed.). New Transnational Social Spaces. International Migration and Transnational Companies in the Early Twenty-first Century. London: Routledge, 3-33.

32. Pries, L. (2005). Configurations of Geographic and Societal Spaces: A Sociological Proposal between 'Methodological Nationalism' and the 'Spaces of Flows'. Global Networks, 5 (2): 167-190.

33. Pries, L. (2008). Die Transnationalisierung der sozialen Welt. Frankfurt a/M: Suhrkamp. 
34. Sartori, G. (1984). Guidelines for Concept Analysis, in: Sartori, G. (Ed.). Social Science Concepts. A Systematic Analysis. London: Sage, 15-72.

35. Sheller, M. and Urry, J. (2006). The new mobilities paradigm. Environment and Planning, 38 (2): 207-226.

36. Simmel, G. (1903/1995). Soziologie: Untersuchungen über die Formen der Vergesellschaftung. Gesamtausgabe, Band 11. Edited by Ottheim Rammstedt. Frankfurt, a/M: Suhrkamp.

37. Soja, E. (1996). Thirdspace: Journeys to Los Angeles and Other Real-and-Imagined Places. Oxford: Blackwell.

38. Sorokin, P. (1998). Social Mobility. London: Routledge Thoemmes Press.

39. Steinmetz, G. (2016). Social fields, subfields and social spaces at the scale of empires: explaining the colonial state and colonial sociology. The Sociological Review Monographs, 64 (2): 98-123.

40. Urry, J. (2000). Sociology beyond Societies. London: Routledge.

41. Vertovec, S. (2003). Migration and other Modes of Transnationalism: Towards Conceptual Cross-Fertilization. International Migration Review, 37 (3): 641-665.

42. Voigt-Graf, C. (2004). Towards a Geography of Transnational Spaces. Global Networks, 4 (1): 25-49.

43. Warf, B and Arias, S. (Eds.) (2009). The Spatial Turn: Interdisciplinary Perspectives. London: Routledge.

44. Weiss, A. (2005). The Transnationalization of Social Inequality: Conceptualizing Social Positions on a World Scale. Current Sociology, 53 (4): 707-728.

45. Wimmer, A. and Glick Schiller, N. (2003). Methodological Nationalism, the Social Sciences, and the Study of Migration: An Essay in Historical Epistemology. International Migration Review, 37 (3): 576-610.

46. Zechner, M. (2017). Transnational habitus at the time of retirement. Identities, 24 (5): 573-589. 
Pregledni rad

\section{Saša Božić}

Sveučilište u Zadru, Odsjek za sociologiju, Hrvatska

e-mail:sbozic@unizd.hr

Simona Kuti

Institut za migracije i narodnosti, Zagreb, Hrvatska

e-mail:simona.kuti@imin.hr

\section{Socijalni prostor i transnacionalni socijalni prostor: kako istraživati kariku koja nedostaje?}

\section{Sažetak}

Proliferacija istraživanja i objavljivanja o transnacionalnom socijalnom prostoru (TSP) i transnacionalnom socijalnom polju u posljednjim dvama desetljećima ukazuje na to da pitanja društvenih veza preko granica nacija-država sve više prevladavaju, počevši od tzv. transnacionalnog obrata u društvenim znanostima i, naročito, migracijskim studijama. Ipak, koncepti koji bi trebali precizno pokriti relevantne fenomene koji se tiču prostornog sastava društvenih veza i aktera preko nacionalnih granica dosta se razlikuju i pokazuju da koncepti utemeljeni na sličnoj ili istoj terminologiji izražavaju različita shvaćanja prostora, društvenih veza i njihove povezanosti. Nemoguće je redefinirati socijalne prostore i TSP-ove bez umnažanja njihovih značenja i stvaranja daljnje zbrke oko granica i smisla tih pojmova. Zato autori ovoga rada nastoje identificirati područja koja sadrže spojnice između koncepata i teorija o socijalnom prostoru kao fizičkom izražavanju društvenih odnosa te koncepata i teorija TSP-a. Autori također naglašavaju područja teoretiziranja o socijalnom prostoru i TSP-u koja zaslužuju posebnu pažnju u budućim istraživačkim nastojanjima da se objasni prostorna konfiguracija društvenog pozicioniranja i društvenih odnosa u pojedinim empirijskim slučajevima, kako bi se doprinijelo (budućoj) usklađenosti barem dijela društvenoznanstvene terminologije i koncepata. Konačno, kako bi se postiglo više discipline u raspravama o socijalnom prostoru i TSP-u, ovaj rad predlaže „postupak“ koji bi se mogao provesti prije upotrebe postojećih pojmova i koncepata u proučavanju određenog društveno-prostornog fenomena koji se proteže preko granica nacija-država.

Ključne riječi: socijalni prostor, transnacionalni socijalni prostor, transnacionalno socijalno polje, transnacionalizam, metodološki nacionalizam. 